\title{
Economic and Technical Feasibility of AnchoisFert Organic Fertilizer Production
}

\author{
Rosaria Ciriminna, ${ }^{1}$ (๑) Antonino Scurria, ${ }^{1,2}$ Daniela Maria Pizzone, ${ }^{2} \bullet$ Paolo \\ Salvatore Calabrò, ${ }^{2}$ Adele Muscolo, ${ }^{3}$. Francesco Mauriello, ${ }^{*} \bullet$ and Mario \\ Pagliaro $^{* 1}$
}

\begin{abstract}
Istituto per lo Studio dei Materiali Nanostrutturati, CNR, via U. La Malfa 153, 90146 Palermo, Italy
${ }^{2}$ Dipartimento di Ingegneria Civile, Energia, Ambiente e Materiali, Università Mediterranea di Reggio Calabria, via Graziella, Feo di Vito, 89122 Reggio Calabria (Italy)
\end{abstract}

${ }^{3}$ Dipartimento di Agraria, Università Mediterranea di Reggio Calabria, Feo di Vito, 89124 Reggio Calabria (Italy)

\begin{abstract}
Is the production of the "AnchoisFert" organic fertilizer via the circular economy process based on omega-3 lipid extraction of milled anchovy fillet leftovers with citrus limonene followed by mild drying economically and technically viable? This study answers this question and identifies the main obstacles, chiefly of economic and organizational nature, to be overcome prior to commercialization of this new organic fertilizer. Along with non-variable and proven efficacy, successful competition with conventional organic and inorganic fertilizers requires affordable cost and regular supply. This, inter alia, requires to establish new and mutually beneficial relationship between bioeconomy firms and fish processing companies.
\end{abstract}

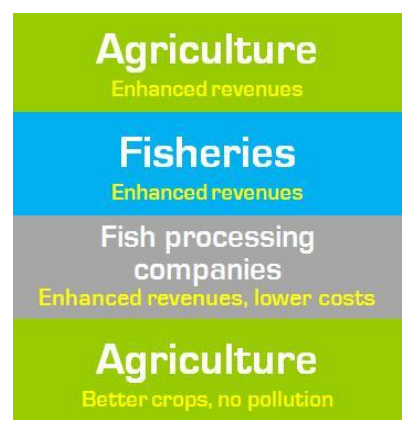

KEYWORDS: AnchoisFert; Fish waste; Green extraction; Limonene; Organic fertilizer

\section{INTRODUCTION}

We have recently reported the discovery of "AnchoisFert", an highly effective organic fertilizer consisting of the solid residue of milled anchovy fillet leftovers extracted with biobased limonene. ${ }^{1}$ The process makes use of an agricultural by-product derived from the orange peel used used both as lipid and vitamin D extraction solvent and as antimicrobial. ${ }^{2}$ In other words, it starts with an agricultural resource and ends benefiting agriculture (Scheme 1)

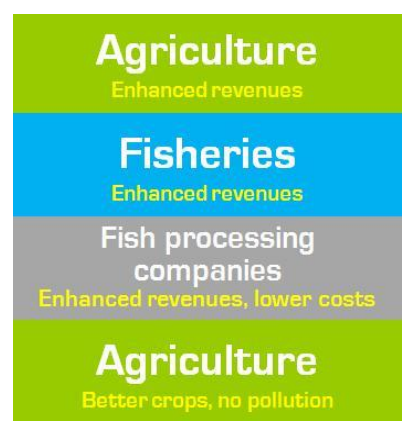

Scheme 1. The value chain actors involved in the production and utilization cycle of AnchoiFert.

In other words, the process closes the fishing material cycle for anchovy fishing fulfilling the main objective of the food "waste-to-value" approach by a new and efficient circular production loops in which fish biowaste is used as raw material for high value molecules and biomaterials.

Numerous fertilizers derived from fish waste are commercially available, especially in the three North American countries. ${ }^{4}$ Nearly all of them, however, are derived from fish waste via chemical, enzymatic or thermal processing such as fish hydrolysate (requiring chemical or enzymatic hydrolysis), ${ }^{5}$ fish emulsion (requiring heating and skimming process) or fish silage (a liquid product made from fish parts liquefied by natural enzymes).
Extraction of fish oil from anchovy fillet leftovers with antimicrobial limonene affording "AnchoisOil", 5 does not require any chemical or enzymatic treatment of fish waste. Furthermore, limonene stabilizes fish waste against microbial spoilage.

As put it by Petrova and co-workers, the main obstacle to fish by-product utilization is of logistic nature because spoilage prevention requires quick transportation of fish waste to processing plants. $^{6}$ Finally, as recently highlighted by Kruijssen and co-workers, little assessment of the impact of intervention efforts to tackle loss and waste in fish value chains has been published, with potential negative impacts on fisheries and consumers rarely considered.

This study investigates the economic and technical feasibility of the "AnchoisFert" production via the circular economy process based on lipid extraction of anchovy fillet leftovers with citrus-derived limonene. ${ }^{1} \mathrm{We}$ focus on Italy's anchovy fillet industry, and identify the main obstacles to be overcome prior to commercialization of this new organic fertilizer. The results, however, are of general value. Along with proven efficacy, affordable cost and regular supply throughout the year are important factors to successfully compete with conventional organic and inorganic fertilizers. The effects of many organic fertilizers on crop yield, indeed, are often variable and slow, ${ }^{8}$ leading farmers to prefer chemical fertilizers regardless of environmental problems due to accumulation of inorganic acids, organic pollutants and heavy metals in groundwater ${ }^{9}$ and soil, ${ }^{10}$ as well as depletion of organic carbon in soil. On the other hand, the cost of chemical fertilizers is high and continuously growing making their use economically not viable for many farmers. ${ }^{1}$

\section{RESULTS AND DISCUSSION}

The ten most caught fish species account for 33\% of global captures. ${ }^{12}$ Amounting to $11 \%$ of the world's total landings, anchovy, and Peruvian anhooveta (Engraulis ringens) in particular, is by far the most caught fish species in the world. In 2018, 7.045 million tonnes of Peruvian anhcoveta and 0.957 million tonnes of Japanese anchovy (Engraulis japonicus) were fished, with the ten most caught species accounting for 
of by far the largest producer of European anchovy (Engraulis

Table 1. Top 4 countries for European anchovy fished in 2015 (Reproduced from Ref.13, with kind permission).

\begin{tabular}{ll} 
Country & Catches (tonnes) \\
Turkey & 193.492 \\
Spain & 49.982 \\
Russia & 45.683 \\
Italy & 37.511 \\
\hline
\end{tabular}

Anchovies are sold fresh or canned as canned fillets. Canned anchovies are prepared by a process of salting and ripening in sunflower or olive oil. During salting, marine salt diffuses into the fish lowering the water content and preventing the growth of spoilage bacteria. During ripening in oil, namely under anaerobic conditions which limit oxidation of polyunsatured fattly acids abundant in anchovy fat, a number of biochemical processes driven by enzymes decompose proteins and fats, ${ }^{14}$ eventually affording soft anchovy fillets widely considered a gourmet speciality.

2.1 Italy's anchovy industry. In Italy, production of European anchovy peaked in 2006 at more than 81,000 t, followed by a sharp reduction that reached a minimum of $29,6644 \mathrm{t}$ in 2013 (Figure 1). ${ }^{15}$ Since then, catches have risen again crossing in 2017 the 38,000 tonnes threshold $(38,151) .{ }^{16}$

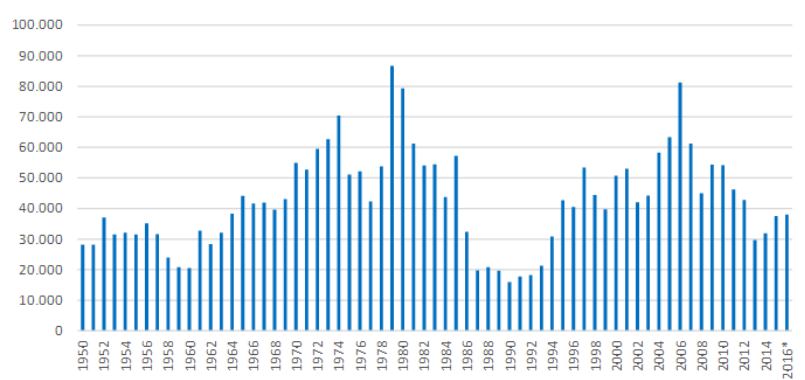

Figure 1. Italy's landings of European anchovy (1950-2016) in tonnes (Reproduced from Ref.13, with kind permission).

Alone, European anchovy and European pilchard (Sardina pilchardus) represent more than one third of Italian marine catches in terms of economic value, with anchovies being generally paid at substantially higher market price. ${ }^{17}$ The species spawns in coastal areas from March to September. ${ }^{18}$ Accordingly, prices for example in Sciacca, the main small pelagic fishing port in Sicily, inversely correlate with landings between March and September. ${ }^{19}$

For comparison, the Sciacca anchovy processing industry produces about 5,000 tonnes of small pelagic fish each year generating about $€ 30$ million revenues. ${ }^{20}$ Along with the fraction of the catch consumed fresh, a significant fraction of anchovies are used for producing anchovy fillets in dedicated plants. Only in Sciacca, more than 1,000 workers are occupied in the anchovy processing industry. ${ }^{20}$ Highlighting the critical impact of marine currents on the socio-economic performance of a fishery, a recent model describing the hydrographic variability and biomass fluctuations of European anchovy in the central Mediterranean sea allows to provide a monetary estimation of catches, derived from different transport dynamics. $^{21}$

In brief, a higher anchovy biomass in this Mediterranean sea area is recorded when a favourable combination of advective currents and egg deposition is observed in the previous year, because coastal current delivers anchovy eggs and larvae alongshore, from the spawning ground of Sciacca to the recruitment area off Cape Passero, in southern Sicily. ${ }^{21}$ and Italy (Table 1).

Each adult (1-2 years old) anchovy in this area of the Mediterranean sea weights $\sim 13.2 \mathrm{~g},{ }^{22}$ with landings showing great annual variability between 1000 and $>5000$ tonnes.

To produce $1 \mathrm{~kg}$ of anchovy fillets preserved in oil $2.25 \mathrm{~kg}$ of anchovies are needed. ${ }^{13}$ This means that $0.55 \mathrm{~kg}$ of anchovy biowaste is available for producing AnchoisFert every kg of anchovy processed. Production of anchovy fillets preserved in oil in Italy amounted to $3,951 \mathrm{t}$ in 2016 , with 8 companies responsable for $80 \%$ of the national production $(\sim 3000 \mathrm{t})$, and the remainder $20 \%$ produced by smaller companies. ${ }^{1}$

To dispose of anchovy fillet waste fish processing companies face an economic cost. In Sicily, for example, in 2021 the typical tariff paid for disposal currently stands at $€ 0.2 / \mathrm{kg}$, if the composting plant where the biowaste undergoes composting with other biological residues is within $100 \mathrm{~km} .{ }^{23}$ Otherwise, a substantially higher tariff will be paid. At the aforementioned production rate of anchovy fillets amounting to $3,951 \mathrm{t}$ in 2016 , this means that Italy's anchovy processing companies purchased 8,979 tonnes of fresh anchovies, 55\% of which (4938 t) were disposed of as biowaste.

2.2 Organic fertilizers: cost and problems. The main problem with organic fertilizers limiting their uptake by farmers is their performance when compared to chemical fertilizers, since their effect on crop yield is often slow and variable. $^{8}$ Furthermore, the price paid by farmers is often similar for both manure and chemical fertilizer. In Italy, for example, the price for both class of fertilizers currently stands at $€ 0.72-0.76 / \mathrm{kg}$, with the fertilizers packed in $25 \mathrm{~kg}$ bags sold at €18-19. ${ }^{24}$ Generally derived from manure obtained from intensive animal farming using large amounts of antibiotics, furthermore, most organic fertilizers significantly increase the abundance (and number) of antibiotic resistance genes in fertilized soil and crops and antibiotic resistance genes. ${ }^{25}$ Finally, with the exception of digestates from agricultural energy crop digesters, organic fertilizers from biowaste fermentation and composting plants contain microplastic particles that progessively contaminate soil. ${ }^{26}$

2.3. AnchoisFert production cost. The cost of manufacturing AnchoisFert (COM) is the sum (Eq.1) of the direct manufacturing cost (DMC), the fixed (indirect) manufacturing cost (FMC), and general expenses (GE): ${ }^{27}$

$$
\mathrm{COM}=\mathrm{DMC}+\mathrm{FMC}+\mathrm{GE}
$$

The direct manufacturing cost is composed of the costs of raw material (CRM), operational labor (COL), utilities (CUT, including electricity and cooling water) and waste treatment (CWT). ${ }^{27}$ In the case of anchovy biowaste, the CRM is zero, whereas the extraction process does not generate any waste, zeroing also the CWT. The only expenses in the DMC voice are those of operational labor cost and of the electricity needed to recover the agrosolvent limonene.

Though expensive (price in late 2017 already exceeded $\$ 7 / \mathrm{kg}),{ }^{28}$ the cost of limonene has little impact on the overall DMC because the biosolvent will be used for numerous extraction cycles, splitting its cost over said numerous extraction cycles. This has been shown in the case of rice bran oil extraction, ${ }^{29}$ and was found to be true also on the laboratory-scale extraction of AnchoisOil.

The FMC costs in Eq.1 are called "fixed" because they do not depend on production rate and are paid even if the process is halted. ${ }^{27}$ They simply consist og the equipment, maintenance depreciation, taxation and insurance (the latter paid to protect the company, generally $1-3 \%$ of fixed capital investment) expenses. 
Finally, the general expenses (GE) are those needed to maintain the business, including administrative (salaries and other administration costs), sales (marketing, product delivery, and other costs related to sales), and research and development costs. ${ }^{27}$

Production of AnchoisFert (and AnchoisOil) via the agitated bed extraction (ABE) simply consists in placing a known mass of milled fish biowaste immersed in a known volume of limonene solvent inside an agitated tank. The scaled up process will employ the same convenient solid:solvent ratio (1.3:1) demonstrated on laboratory scale. ${ }^{5}$ The extraction takes place in $12 \mathrm{~h}$ only and does not require any heating, being carried out at room temperature starting from milled frozen anchovy biowaste mixed with cold limonene (kept at $4{ }^{\circ} \mathrm{C}$ ). 5

Among new and conventional extraction technologies such as ultrasound-assisted, pressurized liquid, and soxhlet extraction, as well as their combination, $\mathrm{ABE}$ was found to be by far the most economically convenient. ${ }^{30}$ The equipment ideally consists of two extractors, extract-solution tank, pump, evaporator, condenser, and recycled solvent tank. A second extraction vessel allows to carry out a continuous process in which while one of the vessels is under operation, the other one goes through the cleaning and recharging processes. ${ }^{30}$ Further supporting investment on industrial scale extraction, the COM in Eq.1 is inversely proportional to the extractor capacity, rapidly diminishing with the size of the extraction vessel (for example, it decreases by $>40 \%$ when the extractor capacity is raised from 0.05 to $0.3 \mathrm{~m}^{3}$ ). ${ }^{30}$

Accurate estimates of the production costs in different parts of the world, with different taxation regimes, labor and electricity costs can be readily obtained via process simulation using a state of the art software affording the capital and manufacturing costs. ${ }^{27,30}$ What is relevant to this analysis is that both capital and operational expenses for $\mathrm{ABE}$ are generally low.

As it happens when using conventional technologies for natural product extraction at industrial level, the amount of labor (COL) required is relatively high, because the simple extraction technology has a low degree of automation. ${ }^{27}$ To lower the DMC costs it is therefore convenient for the companies that will manufacture the AnchoiSoil fish oil and the AnchoisFert fertilizer to install a photovoltaic energy generation array coupled to an energy storage system. ${ }^{31}$ This will significantly reduced the CUT costs of the electricity used in the process to recover the solvent. From Turkey to Sicily, to the Azov Sea, the European anchovy is fished and processed in Mediterranean and Black Sea regions with high levels of solar irradiation that allow to self-generate plentiful electricity during the whole year.

2.4. Obstacles to overcome. Given the low production cost of both AnchoisOil and AnchoisFert, the main obstacles to be overcome prior to production and commercialization of these new bioproducts are of economic and organizational nature.

In general, the anchovy processing companies are highly profitable firms able to easily face the disposal costs of the fillet biowaste. For example, at $€ 0.2 / \mathrm{kg}$ disposal cost, Italy's anchovy fillet companies processing companies processing 8,979 tonnes of fresh anchovies, 55\% of which (4938 t) are biowaste would share about $€ 1$ million $(€ 987,750)$ disposal costs. The high revenues of these companies, overcoming €30 million only in Sicily's Sciacca area, ${ }^{20}$ perhaps explain why anchovy fillet residues so far have been simply disposed of as food production waste.

Furthermore, microbial spoilage of said waste obtained after degutting and beheading the anchovy is very quick due to enzymatic autolysis, oxidation, and microbial growth is very quick. Most bacteria and digestive enzymes indeed are located in the digestive system causing rapid autolysis and deterioration. ${ }^{32}$ This implies that the oil and fertilizer production plant will need to be installed directly at the manufacturing site, or in its close proximity.

A fish oil of high quality such as the AnchoisOil, rich in omega-3 lipids in natural form, oleic acid, and vitamin D in its most bioavailable form (vitamin $D_{3}$ ), ${ }^{33}$ is a high value bioproduct that can be commercialized for nutraceutical applications at higher price than conventional, highly refined fish oil made available in diethyl ester form. ${ }^{34}$ The same trend, for example, is observed for fish oil including natural antioxidants and added vitamin D. ${ }^{35}$ Further economic value for the bioeconomy company producing the bioproducts from anchovy fillet biowaste will originate from the sales of the AchoisFert organic fertilizer.

Under these conditions, no anchovy processing companies would accept to simply become the supplier of low cost raw material. More likely, the management of the anchovy fillet company would seek a mutually beneficial partnership with the producer of omega-3 lipids and organic fertilizer, thereby becoming a bioeconomy company. As the bioeconomy unfolds across the world, ${ }^{36}$ this shift today is common to several agri-food companies engaged in agri-food waste valorisation, including rice, citrus and fish processing companies that will try "to establish strategic partnerships [that] could facilitate the connections needed for the valorisation of residues, and in particular contribute to ensure that resources can flow between sectors in a constant and efficient way". 3

\section{CONCLUSIONS}

Recycling scarce minerals and other nutrients from the sea and back to terrestrial environments solid fish waste is already processed to produce commercial organic fertilizers for organic horticulture in different countries. ${ }^{4}$ Readily obtained from anchovy fillet biowaste after fish oil extraction with orange-derived limonene, AnchoisFert is a new organic fertilizer whose production does not require chemical, enzymatic or thermal processing of fish biowaste. ${ }^{1}$

This opens the route to large-scale production of this new organic soil and plant nutrient via a low cost and low-energy production setup, in which the main operational costs are due to labor and electricity to separate the oil from biobased solvent. Given the low production cost of both AnchoisOil and AnchoisFert, the main obstacles to be overcome prior to commercialization of these bioproducts are of economic and organizational nature.

The interests of the supplier (the agri-food company) and the transformer (the bioeconomy company) engaged in the valorisation of agri-food residues must be aligned, ideally in the form of a jointly owned new firm.

The new bioeconomy will need both young managers and young technologists acquainted with the key enabling technologies of the bioeconomy, starting from the green extraction of natural products, ${ }^{38}$ as well as in integrating the activities of companies previously working in widely different markets.

Rather than waiting for the development of a suitable "regional environment for bioeconomy entrepreneurship [making available] various forms of formal and informal support", ${ }^{39}$ the new bioeconomy company should proactively act identifying and hiring the aforementioned new personnel, learning from the highly successful cases of many bioeconomy companies whose success goes back to the early 1900s.

One example is the pectin industry, ${ }^{40}$ whose prolonged success relies on the availability of good quality lemon peel from lemon juice companies. For several decades the industry supplied a relatively low amount (a few 10,000 tonnes per year) of highly profitable pectin to meet a slowly growing 
global demand using dried lemon peel chiefly shipped from Argentina. When the global demand of pectin rose to today's levels (70,000 tonnes, and counting), supply of dried lemon peel was no longer sufficient. Hence, the industry built several new plants close to citrus juice production plants using as raw material the fresh peel of orange, lime and lemon peel in place of dried lemon peel only.

A similar trend, we forecast in conclusion, will now impact the "fish biorefinery" using fish biowaste to produce high value end bioproducts (i.e., not ethanol or biogas) from readily degraded fish biowaste available in huge amount, though scattered amid many producers. Being a powerful antimicrobial (and antioxidant) already used to stop spoilage in fish, ${ }^{41}$ and enabling the concomitant production of a new marine oil $^{5}$ and organic fertilizer residue, ${ }^{1}$ orange-derived limonene will play a crucial role in the new fish biorefinery starting from the most fished species across the seas. Its successful utilization in extracting an astaxanthin-rich marine oil from shrimp waste, indeed, has been already demonstrated. ${ }^{42}$

Actually, in conclusion, stabilization against microbial spoilage with limonene, and subsequent extraction of fish biowaste with the same biosolvent producing fish oil and organic fertilizers, is ideally suited for the Mediterranean fishing industry targeting the fresh consumption market.

A system for withdrawal and storage of fishery discards on the territory based on stabilization of discards immersed in cold limonene could be established at limited financial costs. Remarkably, the structure of Italy's fishing industry with hundreds of vessels scattered over more than $8000 \mathrm{~km}$ of coast in hundreds of landing points, was lately identified as the main barrier to the full utilization of unwanted catches for the fishing operations in the Mediterranean Sea. ${ }^{43}$ Perhaps not surprisingly, in fact, Germany, France and Spain host selected companies that successfully produce fish oil, fishmeal and fish protein hydrolysates for the animal feed, cosmetic and nutraceutical markets at production sites (for example, in Boulogne-sur Mer and Concarneau in France, Artabra in Spain, Cuxhaven in Germany) located in close proximity to large fish processing plants. ${ }^{44}$ This ensures a nearly constant supply of high-quality fish by-products at relatively low cost.

A forthcoming study will explore the feasibility of the aforementioned model for Mediterranean fisheries.

\section{AUTHOR INFORMATION}

\section{Corresponding Authors}

${ }^{\star}$ E-mail: mario.pagliaro@cnr.it (M.P.)

${ }^{\star}$ E-mail: francesco.mauriello@unirc.it (F.M.)

\section{Notes}

The authors declare no competing financial interest.

\section{ACKNOWLEDGMENTS}

This article is dedicated to Professor Maria Angela A. Meireles, State University of Campinas, Brazil, for all she has done to advance green natural product extraction technologies. We thank Dr Fabio D'Agostino, Istituto per lo studio degli impatti Antropici e Sostenibilità in ambiente marino, CNR, Italy, for providing timely information of blue fish biowaste disposal costs in Sicily.

\section{REFERENCES}

(1) A. Muscolo, F. Mauriello, F. Marra, P.S. Calabrò, M. Russo, R. Ciriminna, M. Pagliaro, AnchoisFert: a new organic fertilizer from fish processing waste for sustainable agriculture, Research Square 2021, doi:10.21203/rs.3.rs-1017059/v1

(2) R. Ciriminna, M. Lomelli, P. D. Carà, J. L. Sanchez, M. Pagliaro, Limonene: a versatile chemical of the bioeconomy, Chem. Commun. 2014, 50, 15288-15296. http://dx.doi.org/10.1039/c4cc06147k

(3) T. Maschmeyer, R. Luque, M. Selva, Upgrading of marine (fish and crustaceans) biowaste for high added-value molecules and bio(nano)-materials, Chem. Soc. Rev. 2020, 49, 4527-4563. https://doi.org/10.1039/c9cs00653b

(4) I. Ahuja, E. Dauksas, J. F Remme, R. Richardsen, A.-K. Løes, Fish and fish waste-based fertilizers in organic farming with status in Norway: A review, Waste Manag. 2020, 115, 95112. https://doi.org/10.1016/j.wasman.2020.07.025

(5) R. Ciriminna, A. Scurria, G. Avellone, M. Pagliaro, A circular economy approach to fish oil extraction, ChemistrySelect 2019, 4, 5106-5109. https://doi.org/10.1002/slct.201900851

(6) I. Petrova, I. Tolstorebrov, T.M. Eikevik, Production of fish protein hydrolysates step by step: technological aspects, equipment used, major energy costs and methods of their minimizing, Int. Aquat. Res. 2018, 10, 223-241. https://doi.org/10.1007/s40071-018-0207-4

(7) F. Kruijssen, I. Tedesco, A. Ward, L. Pincus, D. Love, A.L. Thorne-Lyman, Loss and waste in fish value chains: A review of the evidence from low and middle-income countries, Glob. Food Sec. 2020, 26, 100434. https://doi.org/10.1016/j.gfs.2020.100434

(8) A. Khaliq, M.K. Abbasi, T. Hussain, Effects of integrated use of organic and inorganic nutrient sources with effective microorganisms (EM) on seed cotton yield in Pakistan, Bioresour. Technol. 2006, 97, 967-972. https://doi.org/10.1016/j.biortech.2005.05.002

(9) A.L. Srivastav, Chemical fertilizers and pesticides: role in groundwater contamination In Agrochemicals Detection, Treatment and Remediation, M.N.V. Prasad, Ed., ButterworthHeinemann, Oxford: 2020; pp.143-159. https://doi.org/10.1016/b978-0-08-103017-2.00006-4

(10) Y.-C. Bai, Y.-Y. Chang, M. Hussain, Bin Lu, J.-P. Zhang, X.-B. Song, X.-S. Lei, D. Pei, Soil chemical and microbiological properties are changed by long-term chemical fertilizers that limit ecosystem functioning, Microorganisms 2020, 8, 694. https://doi.org/10.3390/microorganisms 8050694

(11) See for example, Tomato farmers in Kajiado decry high cost of fertilizers, Kilimo Insight, January 18, 2021. http://kilimoinsight.co.ke/tomato-farmers-in-kajiado-decry-highcost-of-fertilizers/

(12) Food and Agriculture Organization of the United Nations, The State of world fisheries and aquaculture 2020, Rome: 2020. https://www.fao.org/publications/sofia/2020/en/ (accessed November 16, 2021).

(13) Direzione generale per gli affari marittimi e pesca della Commissione europea, L'acciuga trasformata in Italia, Bruxelles: 2021. https://doi.org/10.2771/021975

(14) M.M. Hernandez-Herrero, A.X. Roig-Sagues, E.I. Lopez-Sabater, J.J. Rodriguez-Jerez, M.T. Mora-Ventura, Total volatile basic nitrogen and other physico-chemical and microbiological characteristics as related to ripening of salted anchovies, J. Food Sci. 1999, 64, 344-347. https://doi.org/10.1111/j.1365-2621.1999.tb1

(15) Ministero delle politiche agricole e forestali, Alice Aanalisi economica e prospettive di consumo, Rome: 2020. https://ittico.bmti.it/CaricaPdfRegolamenti.do?doc $=6$ (accessed November 16, 2021).

(16) Istat, Statistiche sulla pesca in Italia, uso integrato di indagini campionarie e dati amministrativi, Rome: 2020. https://www.istat.it/it/files/2020/05/IWP-4-2020.pdf (accessed November 16, 2021).

(17) E. M. Quinci, Identificazione delle aree di deposizione e di nursery dell'acciuga europea (Engraulis encrasicolus) nel Canale di Sicilia, PhD Thesis, Università Ca' Foscari Venezia, 2012. http://hdl.handle.net/10579/1209

(18) G. Basilone, C. Guisande, B. Patti, S. Mazzola, A. Cuttitta, A. Bonanno, A.R. Vergara, I. Maneiro, Effect of habitat 
conditions on reproduction of the European anchovy (Engraulis encrasicolus) in the Strait of Sicily, Fish. Oceanogr. 2006, 15, 271-280. http://dx.doi.org/10.1111/j.1365-2419.2005.00391.x

(19) B. Patti, C. Pedroza-Gutierrez, I. Piazza, S. Mazzola. Small Pelagic Fish Market in the South of Sicily: Linkages between catch volume and market price, IIFET 2014 Australia Conference Proceedings, Brisbane, 7-11 July 2014. https://ir.library.oregonstate.edu/concern/conference_proceedings _or_journals/4m90dw65k (accessed November 16, 2021).

(20) B. Patti, C. Pedroza-Gutierrez, I. Piazza, S. Mazzola. Small pelagic fish market in the South of Sicily: linkages between catch volume and market price, IIFET 2014 Australia, Conference presentation, Brisbane, 7-11 July 2014. https://ir.library.oregonstate.edu/concern/conference_proceedings _or_journals/7p88ch63t (accessed November 16, 2021).

(21) A. Di Cintio, M. Torri, F. Falcini, R. Corrado, G. Lacorata, A. Cuttitta, B. Patti, R. Santoleri, Hydrographic variability and biomass fluctuations of European anchovy (Engraulis encrasicolus) in the central Mediterranean Sea: monetary estimations and impacts on fishery from Lagrangian analysis, arXiv 2021, 2106.09437 [physics.ao-ph]. https://arxiv.org/abs/2106.09437v1

(22) S. Mazzola, A. García, J. García Lafuente, The Sicilian Channel anchovy fishery and the underlying oceanographic and biological processes conditioning their inter-annual fluctuations, Commission of the European Communities, Directorate general for fisheries, Project Med 98-070, Final Report, Bruxelles: 2002. https://www.researchgate.net/publication/259254949

(23) F. D'Agostino, Istituto per lo studio degli impatti Antropici e Sostenibilità in ambiente marino, CNR, personal information to M.P., November 2021.

(24) Personal information from selected Italy's fertilizer companies to A.M., November 2021.

(25) F. Wang, W. Han, S. Chen, W. Dong, M. Qiao, C. Hu, B. Liu, Fifteen-year application of manure and chemical fertilizers differently impacts soil ARGs and microbial community structure, Front. Microbiol. 2020, 11, 62. https://doi.org/10.3389/fmicb.2020.00062

(26) N. Weithmann, J. N. Möller, M. G. J. Löder, S. Piehl, C. Laforsch, R. Freitag, Organic fertilizer as a vehicle for the entry of microplastic into the environment, Sci. Adv. 2018, 4, eaap8060. https://doi.org/10.1126/sciadv.aap8060

(27) C.G. Pereira, J.M. Prado, M.A.A. Meireles, Economic evaluation of natural product extraction processes, In: Natural Product Extraction: Principles and Applications, M.A. Rostagno, J.M. Prado (Ed.s), RSC Publishing, Cambridge: 2013; pp.442471.

(28) M. Pagliaro, A. Fidalgo, L. Palmisano, L.M. Ilharco, F. Parrino, R. Ciriminna, Polymers of limonene oxide and carbon dioxide: Polycarbonates of the solar economy, ACS Omega 2018, 3, 4884-4890. http://doi.org/10.1021/acsomega.8b00644

(29) S. X. Liu, P. K. Mamidipally, Quality comparison of rice bran oil extracted with $d$-limonene and hexane, Cereal Chem. 2005, 82, 209-215. https://doi.org/10.1094/CC-82-0209

(30) P. C. Veggi, D. T. Santos, M. A. A. Meireles, Anthocyanin extraction from Jabuticaba (Myrciaria cauliflora) skins by different techniques: economic evaluation, Proc. Food Sci. 2011, 1, 1725-1731.
(31) M. Pagliaro, F. Meneguzzo, Digital management of solar energy en route to energy self-sufficiency, Global Chall. 2019, 3, 1800105. https://doi.org/10.1002/gch2.201800105

(32) A. Bensid, Y. Ucar, B. Bendeddouche, F. Özogul, Effect of the icing with thyme, oregano and clove extracts on quality parameters of gutted and beheaded anchovy (Engraulis encrasicolus) during chilled storage, Food Chem. 2014, 145, 681686. http://dx.doi.org/10.1016/j.foodchem.2013.08.106

(33) A. Scurria, C. Lino, R. Pitonzo, M. Pagliaro, G. Avellone, R. Ciriminna, Vitamin $\mathrm{D}_{3}$ in Fish Oil Extracted with Limonene from Anchovy Leftovers, Chem. Data Coll. 2020, 25, 100311. https://doi.org/10.1016/j.cdc.2019.100311

(34) R. Ciriminna, F. Meneguzzo, R. Delisi, M. Pagliaro, Enhancing and improving the extraction of omega-3 from fish oil, Sustain. Chem. Pharm. 2017, 5, 54-59. http://dx.doi.org/10.1016/j.scp.2017.03.001

(35) See for example the Arctic Omega-3 marine oils blended with oilve biophenol antioxidants and vitamin D: https://ao3norway.com/ (accessed November 19, 2021).

(36) M. Pagliaro, The central role of chemistry in the transition to the solar economy: the outcomes of two lectures at the Russian Academy of Sciences, Gen. Chem. 2020, 6, 200007. https://doi.org/10.21127/yaoyigc20

(37) A. Klitkou, A.M. Fevolden, M. Capasso, Conclusions In From Waste to Value. Valorisation Pathways of Organic Waste Streams in Circular Bioeconomies, A. Klitkou, A.M. Fevolden, M. Capasso (Ed.s), London: Routledge, 2019; pp.293301.

(38) F. Chemat, M. Abert Vian, G. Cravotto, Green extraction of natural products: concept and principles, Int. J. Mol. Sci. 2012, 13, 8615-8627. https://doi.org/10.3390/ijms 13078615

(39) A. Kuckertz, E. S.C. Berger, L. Brändle, Entrepreneurship and the sustainable bioeconomy transformation, Environ. Innov. Soc. Transit. 2020, 37, 332-344. https://doi.org/10.1016/j.eist.2020.10.003

(40) R. Ciriminna, A. Fidalgo, R. Delisi, L. M. Ilharco, M. Pagliaro, Pectin production and global market, Agro Food Ind. Hi Tech 2016, 27, 17-20. https://bit.ly/3wZYYJy

(41) M.A. Ghareaghaji, S. Zomordi, M. Gharekhani, S. Hanifian, Effect of edible coating based on salep containing orange (Citrus sinensis) peel essential oil on shelf life of rainbow trout (Oncorhynchus mykiss) fillets, J. Food Process. Preserv. 2021, 45, e15737. https://doi.org/10.1111/jfpp.15737

(42) A. Scurria, A.-S. Fabiano Tixier, C. Lino, M. Pagliaro, G. Avellone, F. D'Agostino, F. Chemat, R. Ciriminna, High yields of shrimp oil rich in omega-3 and natural astaxanthin from shrimp waste, ACS Omega 2020, 5, 17500-17505. https://doi.org/10.1021/acsomega.0c01978

(43) F. Maynou, G. Kraus, D. Pinello, P. Accadia, E. Sabatella, M. Spinadin, Science, Technology and society initiative to minimize unwanted catches in European fisheries, The science, technology and society initiative to minimise unwanted catches in European fisheries (MINOUW), Horizon 2020 Framework Programme of the European Union, Project 634495, 26 June 2018. http://minouw-project.eu/wpcontent/uploads/2018/11/D2.19-Handling-Storage-Transport.pdf

(44) C. Bisgaard, Collection of discard in European fishing ports challenges and opportunities, Pelagic AC Pelac Meetings, Dublin, 25 April 2017. https://effop.org/wpcontent/uploads/2019/01/bodo_von_holten-iceland-2015.pdf 
